\title{
Standardization, globalization and rationalities of government
}

\section{Winton Higgins and Kristina Tamm Hallström}

\begin{abstract}
As ruler-setters, national standards bodies have enjoyed legitimacy bestowed by representative states, to whose regulatory role they have contributed. As international standards bodies have emerged over the last century, they were until recently simply the sites of negotiations between national bodies. With 'globalization', however, international bodies have lost their links to state sovereignty and come to set agendas for national bodies, instead of vice versa. At the same time, nation-states have apparently relinquished their regulatory authority in favour of 'soft' regulation based inter alia on international standards. Whence comes international standards bodies' authority now?

While acknowledging the institutional novelties, we invoke Michel Foucault's work on governmentality to question claims that they represent a rupture with previous practices of government. On the contrary, we suggest, the further extension of modern rationalities of government into neo-liberal rule from the 1980s lies behind the institutional shifts in question. Neo-liberalism reconfigures the linkages through which power is exercized without in any way abandoning the will to rule.
\end{abstract}

Standardizers develop and publish formal, written standards. For most of their existence, they have largely escaped social-scientific interest; except for occasional notice from economists, they have been consumers of research rather than objects of it. They have appeared to ply a mundane technical calling in ensuring a modicum of convenience and safety in the (usually physical) accoutrements of modern life, one that might not otherwise be there. That calling included supplementing the work of government regulators where the latter deemed fit.

In the last decade, however, standardizers have shown up on socialscientific radar screens, no longer as the unobtrusive servants of modern folk, but as prominent in the ranks of the 'globalized' world's remote, faceless masters (Brunsson et al, 2000). They have taken on the role of regulators of first instance, rather than as minor suppliers of specifications to regulators exercizing the hallowed sovereignty of nation-states. The brave new world of globalization does business differently, it seems, in a way that institutionally outflanks the nation-state's regulation. In this world, standards bodies rank with global market mechanisms and the hierarchical organizations they spawn, to form a power triangle that produces the coordination and 
orderliness in socio-economic affairs which were once the responsibility and privilege of state functionaries (Brunsson, 2000:21).

Since the late 1980s, international standards bodies have issued rules on how an enterprise (and later, any significant organization) should be managed to ensure 'quality', how enterprises should deal with the environmental impact of their operations, how they should manage their risks, their knowledge and complaints made against them, how they should keep their accounts and ensure regulatory compliance and probity in other ways. At the time of writing, the main organ of international standardization, the International Organization of Standardization (ISO), is even developing a standard covering the social responsibility of organisations in such matters as social diversity and access, industrial relations, and north-south trade (Tamm Hallström, 2006). In most instances a formidable global certification and accreditation network contributes moral suasion to (putatively) voluntary compliance with the new managerial standards.

This 'new regulation' confounds our conventional conceptions of legitimacy and authority. In the West at least, the nation-state has been assumed to represent our prime form of political community, legitimate authority and identity. Its rulers have long since ceased to assert a divine right to rule, and instead appeal to public opinion and the ultimate sovereignty of 'the people' who belong to that community, as the unquestionable basis of their authority. Whence comes the authority of the new regulators? Are they not usurpers to whom (the ghost of John Locke might counsel us) we owe no obligation whatever? As Kristina Tamm Hallström (2004) shows, authority is indeed an issue when international standards bodies develop their new quasiregulatory 'deliverables'.

International standards bodies lack roots in state sovereignty, and so appear to be staging something of a revolution against our received notions of political community, authority and legitimacy. Such a view would fit well with the more breathless accounts of globalization, ones which present this condition as a radical discontinuity with the past, especially a past seemingly dominated by sovereign nation-states. However, Michel Foucault (champion of a 'history of the present' that emphasizes continuities) once described such a 'discontinuous' conception of the present as one of 'the most destructive habits of modern thought', a matter we will return to. ${ }^{1}$

This paper will seek his guidance in opening up another perspective on the new role of international standards bodies under conditions of globalization, one based on his notion of rationalities of government, or (in his own coinage) governmentality. We will suggest that standards bodies have been gradually assuming the functions of government since the 1920s, while developing their own technique of rule, and the supporting rhetoric to legitimate it. As Barry Hindess (1996:108) puts it, Foucault uses the term 'government' to mean 'the regulation of conduct through the more or less 
rational application of the appropriate technical means', irrespective of institutional setting or state sovereignty. This focus shifts the emphasis from the institutions to the discursive practices of government in a variety of institutional settings, including both 'public' and 'private' ones. What emerges from this reframing of standardizers' work today is a strong sense of continuity with past conceptions of government, even a whiff of the Nietschean 'eternal return of the same' - a fitting outcome given Foucault's indebtedness to Nietsche's conception of power and penchant for genealogies.

The best way to develop this perspective is to first outline how standardization has emerged as a discursive practice, and how its institutional expressions have evolved to match the stages in this process. The family trees of today's international standards bodies have their roots in the formation of national standards bodies (NSBs) in the West during the early twentieth century. Once we have accounted for their proliferation, we can turn to an overview of ISO's own development. From there we will summarize the development of rationalities of government as such in the modern West, so as to shed theoretical and comparative light on the past and present work of standardizers as accomplices in government. Finally, we will draw some conclusions about how the 'new regulation' exemplifies enduring rationalities of government.

\section{The birth of the national standards body}

On ceremonial occasions eminent standardizers are wont to unfurl a conventional hagiography of their craft from prehistoric times, one deeply rooted in the western legend of rational progress. Language relies on standardized relationships between human sounds and signs on the one hand, and things and actions on the other. Trade depends on standardized physical measurements and terms of exchange based on a currency standard, such as the gold standard. The ancient Babylonians built with bricks of standard dimensions, and the Romans standardized chariot axle lengths to $1435 \mathrm{~mm}$ to economize on road-building. (Rail networks nowadays do likewise, most with exactly the same gauge). And so on.

Standardization gained an altogether new dignity with mechanized production, as the old crafts' unique artefacts gave way to homogeneous manufactures with interchangeable parts. High-volume munitions and arms industries greatly encouraged standardization as a basic principle of process and product engineering. After World War I, the 'second industrial revolution' - based on the mass production of (among other things) cars, household appliances, agricultural machinery, and diesel and electrical motors - relied intensively on standardized components and products, as well as standardized design conventions in precision engineering. 
This development, and the related rise of the engineers themselves as a newly professionalized body to a pinnacle of power and prestige in industry, triggered the emergence of an international (and internationalist) standardization movement in the 1920s. It intertwined with similar 'movements' around industrial 'rationalisation', and 'simplified practice' - the reduction of superfluous variety in manufactures. (De Geer, 1978; Shenhav, 2002; Higgins, 2005:38-43). Early twentieth-century engineering hubris spawned another related development for any serious student of power and control, the engineer F W Taylor's 'scientific management' - the founding moment of today's management discipline. We will come back to it below.

In the 1920s standardizers (at the time all drawn from the engineering profession) clinched their crucial rise, from the mere promoters of a conceptually simple production principle, to being the actual and potential bearers of a number of already-established governmental rationalities, as we will elaborate below. A rash of national 'engineering standards associations' the organized expressions of the standardization movement - sprang into being out of initiatives taken jointly, in the typical case, between industry associations or engineers' professional bodies on the one hand, and national governments on the other. The British (1901), American and German bodies (both 1917) arose a little earlier.

Since the seventeenth century at least, western nation-states have expressly promoted the 'prosperity' of their own populations, including favourable trade. Now governments promoted standards bodies as harbingers of industrial progress and facilitators of trade through the issue of 'specifications' appropriate to export markets. From modest beginnings in such matters as electrical wiring rules, governments for regulatory purposes also began to rely on their NSBs to formalize and keep updated a number of technical details of socio-economically important infrastructures and amenities. NSBs could also become a vital part of national development strategies, including (in cases of late industrialization) basic industrialization and national economic integration, as in Australia. That case also illustrates the fertile links NSBs could develop with scientific research in aid of industrial innovation (Higgins, 2005:31-61). When World War II broke out, NSBs were sufficiently integrated into public economic management and scientific research establishments to prove invaluable linkages in armaments and munitions production (Higgins, 2005:62-80).

National governments were quick to exploit the trade-facilitating role that their NSBs could play. The British empire between the wars illustrates this point (and uncannily prefigures the flurry of activity from the late 1980s around the harmonization of European standards to assist at the birth of an integrated European economy in 1992). As the Whitehall-centred 'empire' step-by-step gave way to a nominally decentralized, federated 'commonwealth of nations', mechanisms for the harmonization of the latter's 
national standards and associated trade-marking arrangements to boost imperial trade (and, soon enough, defence capacity) preoccupied the NSBs of the newly conceived, quasi-sovereign 'dominions'.

The authority of NSBs' published standards rested (and continues to rest) on three linked claims - that they represented the optimal solution to a recurring technical problem; that they arose as consensus solutions out of an open, representative process; and that compliance with them is in principle voluntary. NSBs have adduced these claims in their own quest for authority for their 'national standards', against the standards developed by dominant firms ('proprietary standards') and by industry associations ('industry standards'), both of which lack the representativeness, consensus and transparent developmental process of the NSBs' products. $^{2}$

Despite their entanglements with (and typical financial dependence on) government, most western NSBs have asserted their status as independent voluntary associations, and as such, sturdy representatives of civil society. Each of those engine rooms of standards development - the NSBs' teeming technical committees - claims to bring together experts from (and representatives of) every interest group with a legitimate stake in the standard it is developing.

In Foucauldian terms, standardization emerged as a savoir ('knowledge' as a first approximation) in the late nineteenth century. As Giovanna Procacci (1991:156-57) puts it, a savoir is a crucial 'exchanger' discourse (or discursive practice), one that links 'the analytic-programmatic levels of the "sciences" and the exigencies of direct social intervention'. It forces the scientific projects into contact with 'all the rigidities, inertia and opacity which the real displays in its concrete functioning. And it is precisely in this sense that a savoir can more explicitly assume the viewpoint of power.' By the end of the twenties, the savoir of standardization was finding applications well beyond the engineering world, and references to the latter then began to fade from the official names of the NSBs (Higgins, 2005:62-80; SIS, 1992:35).

In the postwar period the discursive practice of standardization returned to its prewar peacetime applications. But in time - and at the behest of governments and social movements - it also spread to areas even further removed from production principles, especially as the notional 'public good' shifted in emphasis from 'the standard of living' (measured in physical consumption, and ownership of selected consumer durables) to 'the quality of life'. The latter comprised in particular the design, quality, safety and reliability of consumption goods and other modern amenities, and the newborn 'consumer's' right to choose between them on the basis of accurate, detailed information.

NSB leaders - once the intimates of screw threads, tram rails, boilers, cranes, railway fishplates and switching gear - now learned to weigh in on 
discussions of test methods for seat belts, condoms, tampons and the flammability of children's nightwear. And they gained formidable political skills in battles with local councils over backyard pool safety, building codes to meet the anticipated severities of nature, and variable funereal monuments and graphic signage to meet the needs of the new multicultural communities.

As standardizers spread themselves over new fields, governments became more and more dependent on incorporating standards into their regulatory regimes and purchasing routines. Once regulators 'called up' a standard, it ceased to be voluntary and instead became 'mandatory' - or more colloquially, 'grey-letter law'. Since they were heavy consumers of standards, government agencies were well represented on NSBs' boards and technical committees. Starting in West Germany in 1975, national governments also began to formalize their relationships with their standards bodies in 'treaties' or 'memoranda of understanding'. This mechanism boosted their authority, while paradoxically further compromising their status as 'non-government' denizens of civil society.

NSBs' most significant conquest occurred in management standards, starting with those focused on 'quality'. Again, this was an issue that crystallized slowly. Norman Harriman's (1928) classic textbook of standardization notes the arrival of quality standards, albeit ones that applied to products rather than processes. The 1930s saw the foundations laid in the USA for the discipline of quality control management, at the time a statistical approach to managing serial-production processes. The British Standards Institution wanted to use this approach to ensure that mass-produced goods carrying its certification mark actually complied with the standard in question - an application of quality management it wanted to see replicated throughout the empire to reinforce mutual recognition of such marks. ${ }^{3}$

The quality management techniques developed in the 1930s found ready application in armaments industries during World War II, and indeed several NSBs (including those of USA, Britain, Canada and Australia) issued war emergency standards to boost their diffusion. In the postwar world, quality management remained firmly in engineering hands, tied to statistical methods and a creature of defence industries, until the late 1970s. Then, in response to Japanese inroads into the markets of major western consumerdurable industries, both NSBs and the ISO began to develop a new, encompassing notion of quality management, and standards and certification mechanisms appropriate to it. In 1979 ISO set up its now famous technical committee, ISO TC 176, to develop and keep updated quality management standards, and it has been doing so ever since (Tamm Hallström, 2000).

The publication of the ISO 9000 standards in 1987 - followed by updates in 1994 and 2000 - triggered a boom industry, to the benefit of NSBs and ISO alike, in the sale of quality management standards and certification thereto. The seemingly minor neologism, 'quality assurance', marked the 
transformation of the quality concept from a 'hard' engineering one backed up by shop-floor inspection, to a 'cultural', managerial concept supported by audit of control systems (Power, 1999:57-58). We will return to the significance of this shift in the next section. The more entrepreneurial NSBs (and ISO in their wake) treated quality management standards as icebreakers for a raft of other management standards, including environmental management, risk and knowledge management, corporate governance and compliance, complaints and conflict handling, and now social responsibility.

When ISO 9000 first saw the light of day, it was not in response to 'globalization'; the transition to that nebulous condition is conventionally dated to the mid-nineties (Clegg, Kornberger and Pitsis, 2005:453).

Nonetheless, these standards met the needs of a more internationalized division of labour in manufacturing, in which major metropolitan manufacturers sourced components from many different firms and countries. All these links in the supply chain could subvert the quality of final products - the argument ran - in the absence of a mechanism like quality management standards and certification, which promised to prevent defects being 'bought in', and identify component manufacturers who might fail to deliver on time. Similar considerations applied to the other management standards as well, and to service industries. As we all awoke in the mid-1990s to find ourselves 'globalized', we also found that corporate and other organizational life forms in dynamic economies were all starting to march to the same drum.

\section{ISO: from Allied corporal to global sergeant major?}

While we are more concerned in this article with discursive practices than institutions, the latter's genealogies provide some guidance to interpreting the discourses and practices concerned. As the main bearer of 'the new regulation', ISO's provenance warrants at least a casual glance. ${ }^{4}$

After US entry into World War II in December 1941, that country, Britain and its dominions mixed and matched their military hardware with increasing intensity as their respective technological long suits, resource bases and proximity to operational theatres were identified and exploited for the war effort. The NSBs concerned worked frantically to produce the requisite emergency standards to facilitate these technology transfers, including resolving incompatibilities between US engineering-drawing practices and those of the British world. In June 1944 the Allies set up the United Nations Standards Coordinating Committee (UNSCC) - ISO's immediate progenitor to deal more effectively with these issues. Naturally, membership was restricted to the Allied belligerents.

However, even at this stage, the NSBs involved acknowledged the future importance of 'coordination' between national standards for peacetime 
trade. When the UNSCC met for its second plenary session in October 1945, the guns had fallen silent, and the guest list now included friendly liberated countries, plus Mexico and Brazil. A year later, UNSCC's third and last meeting, now including neutral Sweden and Switzerland among 25 participant countries, turned into the inaugural congress of ISO. Then as now, ISO's constituent members were NSBs. But the delegates to its inaugural congress, like those who came to UNSCC meetings, officially represented their national governments, though they were drawn from their NSBs. From that time on, globetrotting delegates from NSBs to international standardization meetings have played an important, publicly subsidized (if usually unofficial) role as diplomatic representatives of trade-maximising national governments. The nation-states were in the business of promoting postwar trade, a business ISO was intended to serve through the alignment of the national standards of potential trading partners on the basis of its published 'recommendations' ${ }^{5}$

ISO's significant watershed came as early as 1970, when - under the influence of its legendary Secretary-General 1968-86, Olle Sturén - it decided it would not only issue 'recommendations', but also publish hitherto unheard-of international standards to pre-empt the content of the relevant national standards. Ideally, NSBs would reissue ISO's products, with minimal or no changes, as national standards. This represented a qualitatively higher level of ambition and a change of function for ISO; it is where its 'quest for authority', in Kristina Tamm Hallström's (2004) phrase, begins in earnest, and continues to this day. Undoubtedly the widespread adoption 'without deviation' of the ISO 9000 series by NSBs as national standards greatly advanced the quest. More generally, international standards have gained salience from many countries' accession to the GATT Standards Code and its successor, the WTO Agreement on Technical Barriers to Trade. Nevertheless, rather like Goethe's freedom, ISO's authority has to be retaken every day by storm.

Globalization thus postdates, and so cannot explain, ISO's emergence as a major rule-setter. Certain aspects of globalization, however, have stimulated demand for its management standards. Clegg, Kornberger and Pitsis' (2005:453-66) account of globalization from a managerial viewpoint can help us to pinpoint what those aspects are. Apart from stimulating even more elaborate international supply chains in real production, globalization has exponentially accelerated 'symbolic trade' - part of 'the global economy of signs' - in capital, currency, intellectual property and (we would now add) standards and other rules. In 'going global', firms have increased the complexity of their corporate strategies and the markets they operate in. A common mechanism in 'going global' is to build strategic alliances and acquire established businesses in target overseas markets. 
Not surprisingly, these strategies attract a great deal of risk and uncertainty; for instance, on one estimate, 70 percent of the mergers and acquisitions fail. As Clegg, Kornberger and Pitsis (2005:466) comment, the resulting global corporate entities more closely resemble dinosaurs than the fleet-footed gazelles of the globalization dreamtime. They need all the neurological aids they can get. Implementation of international management and accounting standards, and the consulting, auditing and certification routines that often depend on them, can - at least to some extent - reduce risk and uncertainty. For this reason both ISO and the NSBs have themselves become major producers and traders of 'signs' (also known as 'weightless exports' or 'deliverables').

At the same time, national governments - and supranational ones such as the EU - have tended to shrink their own regulatory activities governing corporate life, and compensated for this partial withdrawal by increasing the reporting and other compliance obligations on companies, as well as the penalties for non-compliance (Cf Clegg, Kornberger and Pitsis, 2005:466). This trend has opened up yet another promising market for management standards, not least corporate governance and compliance standards, and the sale of standards-related literature such as handbooks and guidelines, together with the attendant paraphernalia of consulting, auditing and certification. Once again, both ISO and the western NSBs are the beneficiaries of the change. ${ }^{6}$

So far we have suggested that 'the new regulation', especially as borne by international standards bodies, is not as new as it may seem. In the main it predates globalization, even if the latter has lent it added momentum in certain ways. We will now suggest that standardization, since it emerged as a savoir in the 1920s, has in fact inherited far older rationalities of government, while also acting as the privileged vehicle of a new, neo-liberal one that has risen to dominance in the last three decades - something we can appreciate if we cease to over-focus on institutional arrangements, and also look at actual practices and rationalities of government throughout the modern period in the West.

The same can be said for standardization's more visible sibling, the discipline of management, sprung from the same engineering loins at roughly the same time. Like standardization, it too has carved out areas of application far removed from its parent discipline. ${ }^{7}$ In the recent period both offspring have prospered and converged, as they have intertwined in the practice of government in the Foucauldian sense, not least in the now dominant neoliberal rationality of government. To understand this convergence, we need to tackle the Foucauldian conception of governmentality. 


\section{Standardization and management as technologies of government}

From the late 1970s until his death in 1984, Foucault broadened the scope of his studies of specific forms of power - especially disciplinary power and biopolitics - into the development and proliferation of governmental rationalities, and of practices dependent on them, throughout the modern period in the West. ${ }^{8}$ Government (crucially understood as an encompassing practice and not as a particular institution) in our own time thus has at its disposal a menu of 'technologies' that has accumulated over the last four centuries. We will suggest below that standardization - also understood as a practice - has been implicated in them all. Since Foucault's death, a whole school of exegetes has systematized his fragmentary literary legacy in the area, and in what follows we will rely on its work.

For Foucault (1991:100) the story - or 'genealogy' - starts with the transition from Machiavelli's problematic in The prince (how a ruler might gain and retain control of a territory he has seized or otherwise acquired) to one concerned with the government of a population. Right from the start, 'government' itself was understood as a practice, 'the conduct of conduct', to be applied to a series of objects - from oneself, through one's spouse, children, household and business, to the social and political entities under one's sway. For instance, $17^{\text {th }}$ century handbooks for rulers typically emphasized that good government began with the ruler's own intimate practice of self-control.

From this bedrock grew the first rationality of government in the series, known in the German states where it arose in the $17^{\text {th }}$ century, as Polizeiwissenschaft, and sometimes 'cameralism' (Pasquino, 1991). This 'police science', which relied heavily on statistics about the population, had little to do with defending law and order - a connotation 'police' acquired only in the late $18^{\text {th }}$ century. Rather, it sought to submit the population to the gaze of allknowing authorities, including through 'statistics' and neo-stoicist confessional practices, so that they might intervene to secure the prosperity of the state and the population (including through mercantilist trading arrangements), and the happiness of the latter understood as a body otherwise incapable of securing these boons for itself. The triad governmentpopulation-security would henceforth become a constant in modern governmentality.

In the Foucauldian lexicon the 'police' conception of government is also called 'the shepherd-flock game', as it constitutes the state as a political pastorate that takes responsibility for the 'flock' as a whole, and for its individual members. The ambit of this 'pastoral' government knows no bounds. The police regulations for the city of Nuremberg in the late middle ages, for instance, dealt with such matters as the use of the familiar secondperson pronoun between parents and children, the dimensions of saddles and 
horsecloths, what could be eaten and drunk at weddings, and so on (Pasquino, 1991).

At least in its original forms, 'pastoral' government depended on state sovereignty and raison d'état, but the remainder of the series of governmental rationalities does not necessarily do so. Foucault is perhaps best known for his study of the origins of 'disciplinary society', and for the associated dethroning of state sovereignty as the crucial element in the exercise of power. ${ }^{9}$ Disciplinary power does not proceed from a sovereign at the centre of government, but is on the contrary 'capillary' - exercised locally according to a variety of discursive techniques in specific 'private' and 'public' institutional settings (Hoy, 1986:131). To the extent that governmental power thus dispenses with reliance on a doctrine of sovereignty, it can also dispense with the legitimacy and authority that state sovereignty normally bestows on its institutional expressions. From now on, the relationship between governmental practices and state institutions is strictly contingent.

Nonetheless, disciplinary society, which began to emerge in the $17^{\text {th }}$ century, exhibits continuities with 'police science'. They include the assumed knowability (through statistics and confessional techniques) of the populations under its sway, themselves conceived very much as the objects of rule in the form of surveillance, regimentation and control, as 'bodies' to be 'drilled' and 'normalized' in armies, prisons, poor- and work-houses, among other paradigmatic settings. The very notion of discipline harks back to government of the self in the pastoral conception of government, as well as anticipating the 'practices of the self' based on self-mastery and selfresponsibility that would later underpin liberal rationalities of government.

As noted earlier, today's management discipline began in 1911 with F W Taylor's 'scientific management', and its genetic link to earlier sites of disciplinary power (for instance, Bentham's panopticonic inspection-house that so fascinated Foucault) hardly needs to be laboured. And as Clegg, Kornberger and Pitsis (2005:19) remind us:

Taylor's system survives today in the way many semiskilled machine-tending tasks are designed in organizations. Elements of Taylorism survive as deeply vestigial organs within modern organizations, but it is not just history. Every time "lean production," "methodologies for total quality management," or "business process reengineering" are introduced into contemporary firms, then an element of Taylorism is being reproduced, because these approaches define the most efficient "one best way" to organize.

In our own time, as we have seen, standardizers tend to follow developments in management disciplines, and seize on such expressions as 'quality' and 
'one best way' as suitable cases for standardization and certification. We will return to this story.

In the $19^{\text {th }}$ century an amalgam of pastoral and disciplinary power began to crystallise, one Foucault calls 'bio-power', to designate, as Colin Gordon (1991:4-5) puts it,

forms of power exercised over persons specifically in so far as they are thought of as living beings: a politics concerned with subjects as members of a population, in which issues of individual sexual and reproductive conduct interconnect with other issues of national policy and power.

A by-product of the interest in the population from this point of view was a certain collusion with another, otherwise antithetical rationality - classical liberalism from the late $18^{\text {th }}$ century. In both cases, the population began to take on a new guise as 'society'.

In spite of its abjuring omniscience in relation to the governed, liberal strategies of government until recent times also relied heavily on 'statistics', and more particularly, social-scientific expertise. This expertise has often privileged economics, but it has also included the disciplines of public administration, political science, sociology, epidemiology, social work and psychology. These disciplines generated the know-how (savoir-faire) which, when fed into public inquiries and other policy-forming bodies, 'render docile the unruly domains over which government is to be exercised, to make government possible and to make government better,' in Nikolas Rose's (1996:45) words.

In the classical-liberal perspective, society is seen as having its own immanent regularities and processes of self-regulation, which define the limits of institutional government, and which have to be known if government is to be effective. The Foucauldian tradition treats liberalism not as an ideology or philosophy, but as a distinctive approach to the art of government - one based on critique of the totalizing pretensions and claims to omniscience of pastoral and bio-political government. To govern well in the liberal mode, one has to work with and through the mechanisms of self-

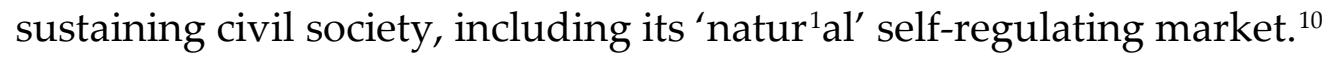

The distinctive feature of liberal rationalities is the treatment of the governed not as the objects of rule, but as formally free subjectivities to be engaged with and coordinated. The governed must become complicit in the processes whereby they are governed. Their free decisionmaking then constitutes not an obstacle to government, but a technical requirement of it. The latter's effectiveness lies in how the subjectivities in question are moulded so 
as to reliably respond to the usual desiderata of government - the constants of security and prosperity (Hindess, 1996:123-131; Gordon, 1991:14-27; Burchell, 1991; Barry et al, 1996:7-16). In this problematic, the ambiguous frontier between state and civil society, between public and private organizations, provides room for manoeuvre for pragmatic practices of government. In their turn, these practices rely on the effects of disciplinary power in producing citizens and their organizations with developed, dependable practices of the self - free agents whose choices are calculable and manipulable for governmental purposes.

The historical account of the western NSBs sketched above illustrates the pragmatic meshing of the government - to adopt Hindess's (1996) term for institutions officially wielding state sovereignty - and 'private' organizations. The practices the NSBs have increasingly engaged in since their emergence in the 1920s, not least as standards have become an essential regulatory mechanism, leave no doubt that they have exercised the functions of government in the Foucauldian sense. Yet their credibility rests on their insistence that, as elements of civil society, they have not been part of - and have worked at arm's length from - the government. They wear the 'nongovernment' accolade with pride.

Nonetheless the intimacy between governments and standards bodies is striking. In most instances governments established them, at least partially funded them, and have been well represented on their boards and committees at all levels. Those belonging to belligerent states during World War II became nodal points in the eminently statist enterprise of waging war, out of which ISO's own immediate predecessor arose. In the affairs of international standards bodies, western non-government NSBs work intimately with nonwestern counterparts which are unashamedly arms of the government in their homelands. A large and growing proportion of the western NSBs' (and these days ISO's) standards now become essential components of the government's normal regulatory and other functions, and most NSBs now have a treaty or memorandum of understanding to put their 'partnership' with the government on a visible, formal footing. And the prospects of any NSB ever manifesting unresponsiveness to the policy impulses issuing from the government are remote.

However, what has attracted academic researchers' interest in standardization in the last decade, we suggest, is not standards bodies' engagement with classical liberal governmentality, but rather with its neoliberal successor. We should note in passing that neo-liberal rule picks up most of the organizational aspects of globalization, such that the latter is in effect a neo-liberal project. The intellectual sources of neo-liberalism go back to the mid-20 th century German school of Ordoliberalen, the postwar writings of Friedrich von Hayek, and the Chicago School and its derivatives, especially public choice theory. The Ordoliberalen contributed the idea that the business 
enterprise models the optimal way for individuals and collectivities to conduct themselves; the Chicago school suggested that all social phenomena and choices are in reality market-economic ones (Gordon, 1991:41-46; Burchall, 1991:22-30). The regimes of Margaret Thatcher and Ronald Reagan put neo-liberalism into practice, and their examples have been followed, to greater and lesser extents, in many other western countries.

While neo-liberalism is still recognizably liberal in founding the activities of government on the free (but disciplined) choices of formally autonomous agents, it has introduced drastic changes into how the governed are to be conceptualized and organized, in order to be reliably complicit in their own government. Unlike classical liberalism, neo-liberalism no longer seeks to maintain governmental functions within society; rather it governs without governing society (Cf Rose, 1996:61). As Margaret Thatcher herself announced in 1987, 'there is no such thing as society. There are individual men and women, and there are families. ${ }^{11}$ For the purposes of neo-liberal rule, society is reframed as a plethora of 'communities', some of them technocratic ones or 'epistemic communities' (Haas 1990). While 'community' picks up resonances of the warm, enfolding Gemeinschaften of pre-modern times that classical sociology made much of, there is nothing at all either gemeinschaftlich or morally self-sufficient about 'the business community', 'the accounting community', 'consumers', 'parents', 'retirees' and so forth that neo-liberal rule conjures forth and builds on.

Rather - to borrow terms coined by Bruno Latour (1986; cf Barry et al, 1996:11-12) - these 'autonomised' groupings (including these days some semidetached state ones) are 'enrolled' to constitute the first points in the 'relays' whereby governmental impulses are sent out. These impulses are then 'translated' into codes of conduct far from government institutions. At the same time, individuals and private organizations face more and more onerous reporting obligations, which ensure that the government can enforce compliance with the codes of conduct in question. In a variety of institutional forms, the 'communities' in question are enrolled in government by entering into 'partnerships' with the government to fulfil regulatory functions on a 'voluntary' basis, just as the NSBs have done. Once again, liberal technologies of government rely not on the imposition of rule on objects of government, but on moulding subjectivities to be responsive to the implicit demands of government, and in this sense to govern themselves and others in their sphere of influence. The perennial liberal rhetoric of small government by no means betokens governing less or abandonment of the will to govern (Rose, 1996:53).

The essence of neo-liberal rule is, then, governing at a distance, to adapt Latour's notion of 'action-at-a-distance' ${ }^{12}$ From its inception in the mid-19 ${ }^{\text {th }}$ century, telegraphy played a vital role in western (not least intercontinental imperial) government, by relaying directives to its operatives manning farflung outposts, and relaying detailed information about the governed back to 
the centre. This 'telegraphic politics' (Barry, 1996:129-132) foreboded - and provides a metaphor for - today's ventriloquistic neo-liberal rule. In place of Morse code, however, there is another process of encryption and translation. As Nikolas Rose (1996:42) puts it, this process consists in 'the translation of political programmes articulated in rather general terms - national efficiency, democracy, equality, enterprise - into ways of seeking to exercise authority over persons, places, and activities in specific locales and practices'.

The generality of the political programmes militates against their translation into substantive terms, as the emergence of 'quality' as a management concept over the last three decades illustrates. Kevin Foley and his colleagues (1997:esp 56-57) rue its vagueness and lack of support in hardnosed scientific theory; Michael Power (1999:58-59) points to its chronic but functional ambiguity; and Johan Quist (2003) shows it to be in need of yet another round of 'translation' if it is to make any difference in practice at the point of production. Thus the true role of the highly abstract ('generic') ISO 9000 quality assurance standards, and of ISO's subsequent management standards, may not lie in encouraging better products, environmental protection and services, but in elaborating 'practices of the self' for corporations. These practices provide a platform for certification, and thus an occasion for recurring audit - a crucial technology of neo-liberal rule at a distance.

International standardization is one of several overlapping supports for the 'audit explosion', a phenomenon that Michael Power brought to public attention in 1994, before ramifying it into a more general analysis of 'audit society', one endlessly proliferating 'industries of checking'. ${ }^{13}$ As Power (1999:42-60) notes, the rise of quality management in particular, and its diffusion into many aspects of public and private organizational life, constitute one of the main factors driving the audit explosion. Quality has to be made auditable, which focuses attention on the formalities of managerial processes rather than the substance of what they produce.

Audit has its own genealogy within the rationalities of government discussed above, one that begins with the practice of confession in the shepherd-flock game', and passes through the inspection-house scenario of disciplinary society, which had long been part of the civil service tradition in many western countries (Gordon, 1991:27). With the arrival of audit society, discipline and inspectability come to play an important part in the practice of government.

Like the earlier forms of submission to authoritative examination, and like the notion of quality, the concept of audit is singularly vague and question-begging, which enhances the auditor's power, including the discretion to liberally interpret public policy. ${ }^{14}$ Audit society promotes - in terms of Michael Power's (1999) subtitle - rituals of verification, which also amount to rituals of obeisance for formally autonomous but effectively 
enrolled organizations. Hype notwithstanding, audits make no contribution to transparency in aid of democratic processes, and are more likely to foreclose questioning than stimulate it (Power, 1999:138, 143).

The organizational effects of government by audit follow the logic of the barium meal - the ingestion of something hardly nutritious or appetizing, but visible to the penetrating diagnostic gaze. Since the favourable outcome of an audit (not least a quality audit) constitutes the hallmark of legitimacy and, for a commercial(ized) organization, a competitive advantage, it can displace substantive goals in the organization's forms of calculation. The latter now prioritize achieving auditability by inserting internal control systems into the organization. As Power (1999:53) observes:

The growing formalization of regulatory layers has generated interest in the internalization of control mechanisms and the validation of their integrity by internal and external audits. New roles have been created, such as financial services compliance officers... and environmental managers..., and new institutional stages have been provided for old roles, such as internal auditors who are an increasingly credible point of reference in public debate. Furthermore there has also been a reworking of inspectorial institutions. With enhanced managerial capability has come greater attention to systems of self-inspection.

To be auditable, then, is to be visible and governable at a distance, rather than to be efficiently pursuing the substantive goals of the organization. 'Audit can provide assurance that the system works well even when substantive performance is poor' (Power, 1999:60).

To adapt a Weberian distinction, audit society represents another triumph of formal over substantive rationality (Higgins and Clegg, 1988). Today's 'rule explosion' (Ahrne and Brunsson, 2004) is one indicator of this triumph. And true to the spirit of neo-liberal marketization, there now flourishes a market in rules on which standards bodies of all varieties compete and thrive (Brunsson et al, 2000). ${ }^{15}$ Once-humble formal standards enjoy a new cachet, and their producers - NSBs and their international derivatives - have achieved a new prominence and profitability as bearers of governmentality, not least if they have subsidiaries in the business of auditing and certifying organizations against their standards. The oft-remarked trend towards the replacement of the laws of sovereign nation-states with standards, norms and rules of varied provenance, embellishes neo-liberal rule-at-a-distance.

As we have seen, all rationalities of government cultivate supportive expertise in forms that reflect their particular logics. Whereas the sociallyoriented governments that immediately preceded the neo-liberal breakthrough privileged substantive, social-scientific expertise, not least in 
policy formation, today's government rests on mastery of formal rationality as embodied in the intellectually lowlier 'grey sciences', above all accounting, auditing and law. ${ }^{16}$ The goal of government is now simply more 'transparently' cost-effective government.

\section{Conclusion}

Standards and standards bodies, including international ones, now play a salient role in regulation, just as many of the organization researchers cited have shown. What is at issue in this article is the degree of novelty in this arrangement, and particularly the apparent takeover of functions, which state authorities once discharged, by non-government standards bodies. We have suggested, following Michel Foucault, reconceptualizing government as a set of practices and supporting rationalities, rather than (as mainstream political theory would have it) as an institutionally defined derivative of the nationstate's sovereign power. If we pursue this idea, then 'the new regulation' including the role of international standards bodies in it - no longer appears to be quite as new or paradoxical as some researchers suggest. Nor is it a creature of recent 'globalization'. National standards bodies have fulfilled a growing regulatory role since their inception in the 1920s, and have, in the course of their development, served most if not all of the modern rationalities of government. In practice, neither the NSBs nor the international standards bodies that they support have ever stood at the distance from state power that they have claimed for self-legitimating purposes. With the coming of neoliberal government from the 1980s, they have thus been in the first rank of 'autonomous' organizations to be 'enrolled' in the business of government.

Is it so strange that these transformations unfold on the stage of globalization? The latter is also a neo-liberal project, supported by key coordinating bodies such as the WTO, the IMF and the World Bank, themselves dominated by major nation-states that have modelled (often in striking form) neo-liberal government. The new global arrangements constitute an extension of - and are of a piece with - the new practices of neoliberal government within national borders as pursued by the government in many western countries.

The consolidation of neo-liberal rule, especially in 'globalized' forms, has entailed some re-arrangement of the institutional furniture, including institutional forms of authority. But beneath it we see a number of syndromes already visible to Max Weber (and many observers since) - above all the pervasiveness of technocratic power, and the usurpation of substantive rationality (and the substantive choices it can generate) by its stunted, formally rational shadow. To quote Erich Maria Remarque, im Westen nichts neues. 
But the authority of international standards bodies faces challenge because these ills that Weber problematized - technocracy and counterproductive formalism - are endemic to their operations, and because their new regulatory functions no longer partake of a state sovereignty underwritten in the last instance by popular sovereignty. The members of the standardizing 'epistemic communities' are essentially self-selecting, as their critics are quick to point out. While Foucault is right to emphasize function over institutions in the practice of government, we should not jump to the conclusion that institutional forms and authority do not matter. They do matter, and for that reason international standards bodies' quest for authority is likely to remain an unfinished project.

\section{Notes}

\footnotetext{
${ }^{1}$ Foucault, quoted in Barry et al, 1996:4. John Braithwaite and Peter Drahos (2000:10) present a somewhat comparable, historically continuous account of business regulation, although they distance themselves from Foucault's method. Most discontinuous accounts of globalization attribute it, improbably, to technological determinants (the Internet, etc) or to some inexplicable deus ex machina.
}

${ }^{2}$ John Boli (1999:273) has theorized this claim to authority by standardizers as an extension of Max Weber's types of authority. Thus they lay claim to 'rational-voluntaristic authority', based not on coercion but freely exercised reason, itself the product of the unconstrained deliberations between putatively equal individuals sitting on technical committees.

${ }^{3}$ Higgins, 2005:56-58. Many NSBs began to introduce conformance marking in the 1930s. The Swedish NSB introduced it in 1936, and bolstered it in 1947: SIS, 1992:36, 59. It was one of the most successful promoters of marking, and enligt svensk standard (according to Swedish standard) became an everyday concept in popular parlance.

${ }^{4}$ See Higgins, 2005:77-86 for an expanded version of the following account.

${ }^{5}$ Higgins, 2005:chs.3 and 4. The UNSCC was not the first initiatives in international standards coordination. Apart from imperial standards conferences held in the interwar period, we should note the formation in 1906 and robust survival to this day of the International Electrotechnical Commission, and the unluckier International Standards Association formed in 1926. The ISA exemplified the 1920s' sanguine sense of an international standards movement, but soon ran into the less uplifting factors of the Depression, the protectionist climate that accompanied it, the divide between metric and non-metric countries, and the 
perception of it as a 'European club' (which for decades would also dog ISO). The ISA was mothballed on the outbreak of World War II, and never reactivated.

${ }^{6}$ For the Australian case and its international ramifications see Higgins 2005:ch.11.

${ }^{7}$ Clegg, Kornberger and Pitsis (2005:18-32) trace the early trajectory, starting with Taylor's Principles of scientific management of 1911, and taking in the much more humanist influences of Elton Mayo (founder of the human relations school) and Mary Parker Follett in the interwar period.

${ }^{8}$ The classic texts of Foucault's earlier period of power analysis are Discipline and punish and The history of sexuality vol. I; the brief canon on governmentality as such took the form of Foucault's 1978 lecture of the same name to the Collège de France (Foucault 1991). The best overview of the area (including a handy glossary of terms) is probably Dean 1999, while Hindess 1996 provides an excellent reconciliation of Foucault's thought with mainstream western political theory.

${ }^{9}$ Foucault 1977. 'We need to cut off the King's head: in political theory that has still to be done,' as Foucault (1980:121) notoriously commented.

${ }^{10}$ As Karl Polanyi's (1944) classic account shows, the coming of liberal government to Britain in the early $19^{\text {th }}$ century saw the crucial markets in question - in land, labour and capital emerge out of energetic (not to say brutal) laissez-faire interventionism. Historically speaking, markets like these are artifices, a point that would become fairly uncontroversial for neoliberal ideologues, such as the Chicago School of the latter $20^{\text {th }}$ century.

${ }^{11}$ Interview in Women's Own, quoted in Dean, 1999:151. As Colin Gordon (1991:46) points out, neo-liberal politicians and governments return to liberalism's self-image as a critique of government, now especially of socially oriented government. They thus present themselves as breaking up a blocked society, one burdened with rigidities and privileges. The present conservative Australian government exemplifies this pattern, especially in dismissing its critics of whatever stripe as 'elites'.

${ }^{12}$ Latour, 1986; Rose, 1996:55-56. The latter (p.40) also describes how 'distant events and persons could be governed "at arm's length".'

${ }^{13}$ Power 1994 and 1999. He describes audit society (1999:122) as 'a society which is increasingly committed to observing itself through various kinds of auditing practice', and as 'a distrusting society' (1999:136).

${ }^{14}$ Power 1999:ch.3 '[I]t is precisely this fuzziness in the idea of auditing that enables its migration and importation into a wide variety of organizational contexts,' Power (1999:6) comments. 'The ambiguity of auditing is not a methodological problem but a substantive fact.' 
15. Kristina Tamm Hallström's (2004) problematic, how standards bodies acquire and claim authority to issue the rules they do and expect others to take them up, is highly relevant to the market in rules and how individual rule-makers pursue competitive advantage. ${ }^{16}$ Rose 1996:55-56. The old problem of technocracy once again rears its head under the aegis of these kinds of experts - see Jacobsson, 2000:48-49, and Sahlin-Andersson, 2000:105-06, 112.

\section{References}

Ahrne, Göran and Nils Brunsson (eds) Regelexplosionen (The Rule Explosion). Stockholm: Stockholm School of Economics.

Barry, Andrew (1996) 'Lines of Communication and Spaces of Rule', in Barry et al, 1996.

Barry, Andrew, Thomas Osborne and Nikolas Rose (eds) (1996) Foucault and Political Reason: Liberalism, Neo-liberalism and Rationalities of Government. London: UCL Press.

Boli, John (1999) 'Conclusion: World Authority Structures and Legitimations', in J. Boli and G. Thomas (eds) Constructing World Culture: International Non-governmental Organization since 1875. Stanford: Stanford University Press.

Braithwaite, John and Peter Drahos (2000) Global Business Regulation. Cambridge: Cambridge University Press.

Brunsson, Nils (2000) 'Organizations, Markets and Standardization', in Brunsson et al, 2000.

Brunsson, Nils, Bengt Jacobsson and associates (2000) A World of Standards. Oxford: Oxford University Press.

Burchall, Graham (1996) 'Liberal Government and Techniques of the Self', in Burchall et al, 1996.

Burchall, Graham, Colin Gordon and Peter Miller (eds) (1991) The Foucault Effect: Studies in Governmentality. Chicago: University of Chicago Press. 
Clegg, Stewart, Martin Kornberger and Tyrone Pitsis (2005) Managing and Organizations: An Introduction to Theory and Practice. London and Thousand Oaks, California: Sage.

Dean, Mitchell (1996) 'Foucault, Government and the Enfolding of Authority', in Barry et al, 1996.

Dean, Mitchell (1999) Governmentality: Power and Rule in Modern Society. London and Thousand Oaks: Sage.

de Geer, Hans (1978) Rationaliseringsrörelsen i Sverige: effektivitsidéer och socialt ansvar under mellankrigstiden (The Rationalisation Movement in Sweden: Concepts of Efficiency and Social Responsibility in the Interwar period). Stockholm: SNS.

Foley, Kevin, Richard Barton, Kerry Busteed, John Hulbert and John Sprouster (1997) Quality, productivity and competitiveness: the role of quality in Australia's social and economic development. Sydney: Wider Quality Movement.

Foucault Michel (1977) Discipline and Punish: The Birth of the Prison. London: Allen Lane.

Foucault, Michel (1980) Power/knowledge (ed. Colin Gordon). Brighton: Harvester.

Foucault, Michel (1991) 'Governmentality', in Burchall et al, 1991.

Gordon, Colin (1991) 'Government rationality: an introduction', in Burchall et al, 1991.

Haas, Ernst (1990) When Knowledge is Power: Three Models of Change in International Organizations. Berkeley: University of California Press.

Hacking, Ian (1991) 'How should we do the history of statistics?', in Burchall et al, 1991.

Harriman, Norman (1928) Standards and Standardization. New York: McGraw-Hill.

Higgins, Winton (2005) Engine of change: Standards Australia since 1922. Blackheath NSW: Brandl \& Schlesinger. 
Higgins, Winton, and Stewart Clegg (1988) ‘Enterprise calculation and manufacturing decline', Organization Studies 9 (1)

Hindess, Barry (1996) Discourses of Power: From Hobbes to Foucault. Oxford and Cambridge Mass: Blackwell.

Hoy, David Couzens (1986) 'Power, Repression, Progress: Foucault, Lukes and the Frankfurt School', in D. C. Hoy (ed) Foucault: A Critical Reader. Oxford and Cambridge, Mass: Blackwell.

Jacobsson, Bengt (2000) 'Standardization and Expert Knowledge', in Brunsson et al, 2000 .

Latour, Bruno (1986) 'Visualisation and Cognition: Thinking with Hands and Eyes', Knowledge and Society: Studies in the Sociology of Culture, Past and Present, 6: 1-40.

Nordström, Anders (2004) 'Reglerare, reglerade och regelskapande processer' (Regulators, the Regulated and Rule-creating Processes), in Ahrne and Brunsson, 2004.

Pasquino, Pasquale (1991) 'Theatricum Politicum: The Genealogy of Capital Police and the State of Prosperity', in Burchall et al 1991

Polanyi, Karl (1944) The Great Transformation: The Political and Economic Origins of our Time. Boston: Beacon Press.

Power, Michael (1994) The Audit Explosion. London: Demos.

Power, Michael (1999) The Audit Society: Rituals of Verification. Oxford: Oxford University Press.

Procacci, Giovanna (1991) 'Social Economy and the Government of Poverty', in Burchall et al, 1991.

Quist, Johan (2003) Att översätta TQM: en longitudinell studie kring reflekterande aktörer (Translating TQM: A Longitudinal Study of Reflexive Actors). Karlstad: Karlstad University Studies.

Rose, Nikolas (1996) 'Governing "Advanced" Liberal Democracies', in Barry et al, 1996. 
Sahlin-Andersson, Kerstin (2000) 'Arenas as Standardizers', in Brunsson et al, 2000.

Shenhav, Yehouda (2002) Manufacturing Rationality: The Engineering Foundations of the Managerial Revolution. Oxford and New York: Oxford University Press.

SIS (1992) Standardiseringen i Sverige 1922-1992 (Standardization in Sweden 1922-1992). Stockholm: Standardiseringskommissionen i Sverige.

Tamm Hallström, Kristina (2000) ‘Organizing the Process of Standardization', in Brunsson et al, 2000.

Tamm Hallström, Kristina (2004) Organizing International Standardization: ISO and the IASC in Quest of Authority. Cheltenham, UK: Edward Elgar.

Tamm Hallström, Kristina (2006) 'ISO enters the field of social responsibility (SR): Construction and Tension of Global Governance', in Folke Schuppert (ed) Global Governance and the Role of Non-state Actors. Berlin: Nomos. 